\title{
Variation in Seedling Vigour of Rice (Oryza Sativa L) Genotypes Treated With Sodium Chloride Solution
}

\author{
Osekita OS*, Babaleye OA, Ajayi AT \\ Department of Plant Science and Biotechnology, Adekunle Ajasin University, Akungba-Akoko Ondo State, Nigeria \\ *Corresponding Author \\ Osekita OS
}

Article History

Received: 08.08.2019

Accepted: 27.08 .2019

Published: 30.09 .2019

\begin{abstract}
This research was conducted to investigate variation in seedling vigour among five genotypes of rice in response to sodium chloride $(\mathrm{NaCl})$ stress administered at $0 \mathrm{~g} / \mathrm{l}, 3 \mathrm{~g} / \mathrm{l}, 6 \mathrm{~g} / \mathrm{l}, 9 \mathrm{~g} / \mathrm{l}$ and $12 \mathrm{~g} / \mathrm{l}$ for germination percentage, final germination percentage, speed of germination, germination energy, plumule and radicle length, plumule and radicle dry weight. The study materials were arranged in a completely randomized design (CRD) replicated three times in the laboratory of Plant Science and Biotechnology, Adekunle Ajasin University, Akungba Akoko Ondo State, Nigeria. The rice genotypes which include; ITA 212, NERICA U-2, NERICA U-7, NERICA U-8 and NERICA L 19 obtained from Africa rice, IITA Ibadan, Nigeria was used for the research. The highest mean FGP was found in the control because no single amount of salinity was applied. The genotypes U-8, U-7, NL-19 and U-2 shows highest germination percentages more than $95 \%$ and ITA212 at $<95 \%$, at $3 \mathrm{~g} / \mathrm{l}$ and $6 \mathrm{~g} / \mathrm{l}$ the genotypes also maintained FGP at above $90 \%$ except for U-7 and ITA that has $<70 \%$ and $30 \%$ respectively. Germination in early seedling growth up to vegetative and reproductive stages of the different five genotypes tested was inhibited by increase in salt concentrations, in respect of final germination percentages, speed of germination and germination energy. The genotypes with high GE\% at specific salinity level obviously would be of higher competitive advantages than genotypes with lower GE\% for capturing environmental and adaptive resources.
\end{abstract}

Keywords: Germination percentage, salinity, plumule, radicle, seedling vigour.

\section{INTRODUCTION}

The demand for rice surpasses population as a result; large quantities of rice are imported with huge cost to meet demand in Africa, a total of 11.6 million tons out of which 3.3 million tons approximating $33.6 \%$ is imported to Africa [1]. However, salinity of soils calls for attention as it plays a prominent role in abiotic stress which adversely affects crop production. It was reported that crop production is impaired by high salinity (Sodium chloride, $\mathrm{NaCl}$ ) of soil and irrigation worldwide [2, 3], this has become a major concern for rice production in the tropical soils. The rising of sea level will lead to sea water intrusion, soil salinization and consequently, cultivated land is aggravated. The salt tolerance is crucial physiological characteristics of crops Yeo and Flower [4] therefore, rice salt tolerance as a quantitative trait is mainly controlled by multiple genes and easily affected by the environmental condition Yeo et al. [5] under salt stress situation, hence phenotypes of the agronomic traits are affected not only by its salt tolerance but also by its own genetic mechanism. In addition improving salt tolerance of crops is necessary for sustainable food production in different saline region [6]. Rice exhibits different salt tolerance at different growth stages Gu et al. [7]. Soil salinity poses a major threat to rice production; particularly along coastal areas during the dry season, these high concentrations of salt can severely impact upon rice plants normal physiology, especially during early stage of growth, and as such farmer are often forced to abandon these otherwise potentially usable areas. The objective of the study is to identify genotypes that are moderately tolerant to salt stress in order to select tolerant genotypes for further breeding improvement programmes.

\section{Materials and Methods}

The experiment was conducted in the laboratory and later transferred to the experimental field of the Department of the Plant Science and Biotechnology, Adekunle Ajasin University, Akungba-Akoko, Ondo state, Nigeria located at latitude $77^{\circ} 37^{1} \mathrm{~N}$ and longitude $5^{\circ} 44^{1} \mathrm{~N}$ elevation of 336-339 $\mathrm{m}$. The five rice (Oryza sativa L.) genotypes were collected from International Institute for Tropical Agriculture (IITA) Ibadan, Oyo state, Nigeria. The genotypes consist of four uplands and lowland rice as listed: ITA 212,

Copyright @ 2019: This is an open-access article distributed under the terms of the Creative Commons Attribution license which permits unrestricted use, distribution, and reproduction in any medium for non commercial use (NonCommercial, or CC-BY-NC) provided the original author and source are credited. 
NERICA U 2, NERICA U 8, NERICA U 7 and NERICA L 19. Healthy and uniform seeds were first selected and viability test carried out by pouring in cold water thereafter, floated seeds were discarded while submerged were air dried. Double surface sterilization was done, with $5 \%$ ethanol for 5 mintues and $10 \%$ was used to avoid micro-organism infection during emergence of seedling and was repeatedly washed with distilled water and surfaced dried. Each cultivar on a petri dish was allowed to grow on a tissue paper, used as substrate of the equal size in a $9 \mathrm{~cm}$ diameter. The petri dishes with each tissue paper were moistened with laboratory salt solution sodium chloride (Nacl.) mixed with water to produce saline solution of different concentrations of $0 \mathrm{~g} / \mathrm{l}, 3 \mathrm{~g} / \mathrm{l}, 6 \mathrm{~g} / \mathrm{l}, 9 \mathrm{~g} / \mathrm{l}$ and $12 \mathrm{~g} / \mathrm{l}$ are also equivalent to as $0 \mathrm{ds} / \mathrm{m}, 6 \mathrm{ds} / \mathrm{m} 12 \mathrm{ds} / \mathrm{m}, 18 \mathrm{ds} / \mathrm{m}, 24 \mathrm{ds} / \mathrm{m}$ respectively.

$5 \mathrm{ml}$ of appropriated solution was applied to each petri dish. The petri dishes were arranged in a Completely Randomized Design (CRD) with three replications for each treatment for each genotype. Germination room temperature was maintained at $22 \pm 1{ }^{\circ} \mathrm{C}$ within 24 hours in a dark cupboard. Plant grows faster in the dark. The number of the seeds that sprouted and germinated was counted from the third day up to the seventh day; two of the seedlings were transplanted into perforated plastic bags of a $24 \mathrm{~cm}$ length and $11 \mathrm{~cm}$ diameter filled with top soil to monitor seedling growth from vegetative to reproductive stages. The perforated plastic bags were arranged using Completely Randomize Design (CRD) of ten (10) per row to screen the genotypes for salinity tolerance.

\section{Data collection}

Data were collected on the following; Speed of germination (SG), Emergence percentage (E \%) and Final germination percentage (FGP) according to the formula described by [9].

$$
S G=\frac{\text { Number of germinated seeds }}{\text { Days of first count }}+---\frac{\text { Number of germinated seed }}{\text { Days at final count }}
$$

$$
E \%=\frac{\text { Number of germinated seeds at fourth day }}{\text { Total number of seed sowed }} \times 100
$$

$$
F G P=\frac{\text { Number of seeds sowed }}{\text { Number of germinated seeds }} \times 100
$$

Seedling and root lengths of 10 randomly selected seedling from each replicate were measure at the time of harvest from the petri dishes (7 days after treatment application) shoot dry weight and root dry weight (10 seedlings) were recorded after oven drying at $70^{\circ} \mathrm{C}$ for 72 hours genotypes were classified based on tolerant (T0 20\% Reduction), moderately tolerant (MT 21 40\% Reduction), moderately susceptible (MS 41 60 Reduction) and Susceptible (S>60\% Reduction) due to different level of salt imposition according to the classification of Fageria [9].

\section{RESULTS AND DISCUSSION}

The research investigated the genetic analysis and performance evaluation of sodium chloride salt stress tolerance in rice (Oryza sativa) in response of five genotypes of rice against five salinity levels $(0,3,6,9$ and $12 \mathrm{~g} / \mathrm{l})$ at germination and early seedling stages. Final germination percentage (FGP), speed of germination (SG), germination energy percentage (GEP), plumule and ridicule length, plumule and radical dry weight, panicle length were also examined. The rice genotypes are ITA212, NERICA2, NERICA7, NERICA 8, and NERICA L 19 as presented under the following heading.

\section{Speed of germination}

The effect of salinity was evident on the speed of germination and significantly decreased in all the genotypes due to increase in salinity levels. Normal growth of each genotype was maintained at control treatment Table 2. At salinity level of $3 \mathrm{~g} / \mathrm{l}$ higher speed of germination of more than $90 \%$ was observed from all the genotypes. At $6 \mathrm{~g} / \mathrm{l} \mathrm{U}-\mathrm{L}-19$ and U- 8 maintained their speed of germination percentages at $90 \%$ and above followed by U-7 which is less than $90 \%$ and U-2 at $<70 \%$ and ITA $<65 \%$. At $9 \%$ and higher concentrations there is reduction in speed of germination percentages. ITA 212 responded poorly to salinity even at control treatment germination percentages was low compared to other genotypes presumably; the osmotic effect due to salinity was the main inhibitory factor that reduced germination as indicated by Akbar, et al. [10].

Table-1: The effect of salinity on speed of germination of five genotypes of rice

\begin{tabular}{|l|l|l|l|l|l|}
\hline GENOTYPES & $0 \mathrm{~g} / \mathrm{l}$ & $3 \mathrm{~g} / \mathrm{l}$ & $6 \mathrm{~g} / \mathrm{l}$ & $9 \mathrm{~g} / \mathrm{l}$ & $12 \mathrm{~g} / \mathrm{l}$ \\
\hline ITA 212 & $19.11^{\mathrm{a}}$ & $17.86^{\mathrm{a}}$ & $11.39^{\mathrm{b}}$ & $2.68^{\mathrm{c}}$ & $1.20^{\mathrm{c}}$ \\
\hline NERICA U-7 & $31.68^{\mathrm{a}}$ & $29.39^{\mathrm{b}}$ & $27.09^{\mathrm{b}}$ & $18.78^{\mathrm{c}}$ & $11.39^{\mathrm{c}}$ \\
\hline NERICA U-8 & $31.68^{\mathrm{a}}$ & $30.59^{\mathrm{a}}$ & $28.40^{\mathrm{b}}$ & $25.63^{\mathrm{b}}$ & $6.97^{\mathrm{c}}$ \\
\hline NERICA L-19 & $31.68^{\mathrm{a}}$ & $30.59^{\mathrm{a}}$ & $29.59^{\mathrm{b}}$ & $25.12^{\mathrm{b}}$ & $17.49^{\mathrm{c}}$ \\
\hline NERICA U-2 & $30.26^{\mathrm{a}}$ & $29.16^{\mathrm{a}}$ & $20.11^{\mathrm{b}}$ & $19.24^{\mathrm{b}}$ & $11.24^{\mathrm{c}}$ \\
\hline
\end{tabular}

Note: Alphabets within the same row are not significantly different 


\section{Final germination percentage (FGP) and germination energy (GE)}

The final germination percentages (FGP) of the rice genotypes at different levels of salinity were presented in Table 2 . It was observed that FGP decreases as the salinity level increases. The highest mean FGP was found in the control because no single amount of salinity was applied. The genotypes U-8, U-7, NL-19 and U-2 shows highest germination percentages more than $95 \%$ and ITA212 at $<95 \%$, at $3 \mathrm{~g} / \mathrm{l}$ and $6 \mathrm{~g} / \mathrm{l}$ the genotypes also maintained FGP at above $90 \%$ except for U-7 and ITA that has $<70 \%$ and $30 \%$ respectively. There are variations in FGP at $9 \mathrm{~g} / \mathrm{l}$ and at $12 \mathrm{~g} / \mathrm{l}$ the results agreed with the findings of Khan et al. [11] that salinity delay germination processes. From the study, it is observed that seed germination is negatively affected by salinity and is thought to be due to both osmotic and ion- toxicity effects and that salinity delay germination in rice with increasing salt stress.

Table-2: The effect of salinity of final germination percentages genotypes of rice

\begin{tabular}{|l|l|l|l|l|l|}
\hline GENOTYPES & $\mathbf{0 g} / \mathbf{l}$ & $\mathbf{3 g} / \mathbf{l}$ & $\mathbf{6 g} / \mathbf{l}$ & $\mathbf{9 g} / \mathbf{l}$ & $\mathbf{1 2 g} / \mathbf{l}$ \\
\hline ITA212 & $93.33^{\mathrm{a}}$ & $90.00^{\mathrm{a}}$ & $30.00^{\mathrm{b}}$ & $23.33^{\mathrm{c}}$ & $10.00^{\mathrm{c}}$ \\
\hline NERICA U-7 & $96.67^{\mathrm{a}}$ & $93.33^{\mathrm{a}}$ & $66.77^{\mathrm{b}}$ & $46.66^{\mathrm{c}}$ & $46.66^{\mathrm{c}}$ \\
\hline NERICA U-8 & $96.97^{\mathrm{a}}$ & $93.33^{\mathrm{b}}$ & $93.33^{\mathrm{b}}$ & $93.33^{\mathrm{b}}$ & $33.33^{\mathrm{c}}$ \\
\hline NERICA L-19 & $96.67^{\mathrm{a}}$ & $93.33^{\mathrm{b}}$ & $93.33^{\mathrm{b}}$ & $76.66^{\mathrm{a}}$ & $66.67^{\mathrm{c}}$ \\
\hline NERICA U-2 & $96.67^{\mathrm{a}}$ & $93.33^{\mathrm{b}}$ & $93.33^{\mathrm{b}}$ & $90.33^{\mathrm{b}}$ & $56.66^{\mathrm{c}}$ \\
\hline
\end{tabular}

Note: Alphabets within the same row are not significantly different

\section{Germination energy}

Germination energy was observed at day four after sowing in petri dishes at different concentrations of $\mathrm{Nacl}^{-}$solution, germination energy reduced significantly Table 3 . Similar trend was recorded at $3 \mathrm{~g} / \mathrm{l}, 6 \mathrm{~g} / \mathrm{l}, 9 \mathrm{~g} / \mathrm{l}$ and $12 \mathrm{~g} / \mathrm{l}$ except in the control treatment which is devoid of salt treatment. The result agreed with the studies conducted by Akbar, et al. [12] and Khan et al. [11] that salinity delays germination processes. In the study some of the genotypes had high FGP but low GE\%, which means that most of the seeds from these genotypes might germinate after 4days of exposure to the various treatments. The genotypes with high $\mathrm{GE} \%$ at specific salinity level obviously would be of higher competitive advantage than those genotypes having lower GE\% for capturing environmental and edaphic resources.

Table-3: The effect of salinity of energy percentages of genotypes of rice

\begin{tabular}{|l|l|l|l|l|l|}
\hline GENOTYPE & $\mathbf{0 g} / \mathbf{l}$ & $\mathbf{3 g} / \mathbf{l}$ & $\mathbf{6 g} / \mathbf{l}$ & $\mathbf{9 g} / \mathbf{l}$ & $\mathbf{1 2 g} / \mathbf{l}$ \\
\hline ITA 212 & $66.77^{\mathrm{a}}$ & $46.67^{\mathrm{b}}$ & $30.00^{\mathrm{b}}$ & $3.33^{\mathrm{c}}$ & $3.33^{\mathrm{c}}$ \\
\hline NERICAU-7 & $96.67^{\mathrm{a}}$ & $93.33^{\mathrm{b}}$ & $90.00^{\mathrm{b}}$ & $80.00^{\mathrm{c}}$ & $60.00^{\mathrm{c}}$ \\
\hline NERICAU-8 & $96.67^{\mathrm{b}}$ & $93.33^{\mathrm{b}}$ & $90.00^{\mathrm{b}}$ & $86.67^{\mathrm{b}}$ & $23.33^{\mathrm{c}}$ \\
\hline NERICA L-19 & $96.67^{\mathrm{a}}$ & $93.33^{\mathrm{b}}$ & $93.33^{\mathrm{b}}$ & $76.67^{\mathrm{c}}$ & $50.00^{\mathrm{c}}$ \\
\hline NERICAU-2 & $93.33^{\mathrm{a}}$ & $90.00^{\mathrm{a}}$ & $83.33^{\mathrm{b}}$ & $76.76^{\mathrm{b}}$ & $23.33^{\mathrm{c}}$ \\
\hline
\end{tabular}

Note: Alphabets within the same row are not significantly different

\section{Plumule and Radicle length}

Figure 1 shows the response of plumule length of all the rice genotypes against salinity treatment which declined relative to the control treatment. However plumule length in the control ranged from $2.4 \mathrm{~cm}$ to $3.6 \mathrm{~cm}$ with NL 19 having the highest plumule length and Nerica U-2 with the lowest plumule length in the control treatment. Plumule length of the rice genotypes responded well at $9 \mathrm{~g} / \mathrm{l}$ concentration and the worst in $12 \mathrm{~g} / \mathrm{l}$. Figure 2 shows the radicle length of the rice genotypes which ranged from $2.5 \mathrm{~cm}$ in Nerica U-2 to $5.6 \mathrm{~cm}$ in both Nerica L 19 and ITA 212 for the control treatment, The graphical display of the various concentrations indicates moderate tolerance of the roots to salinity treatments. The gradual decrease in root length with the increase in salinity as observed might be due to more inhibitory effect of $\mathrm{NaCl}$ salt to the root growth compared to that of the shoot growth [3].

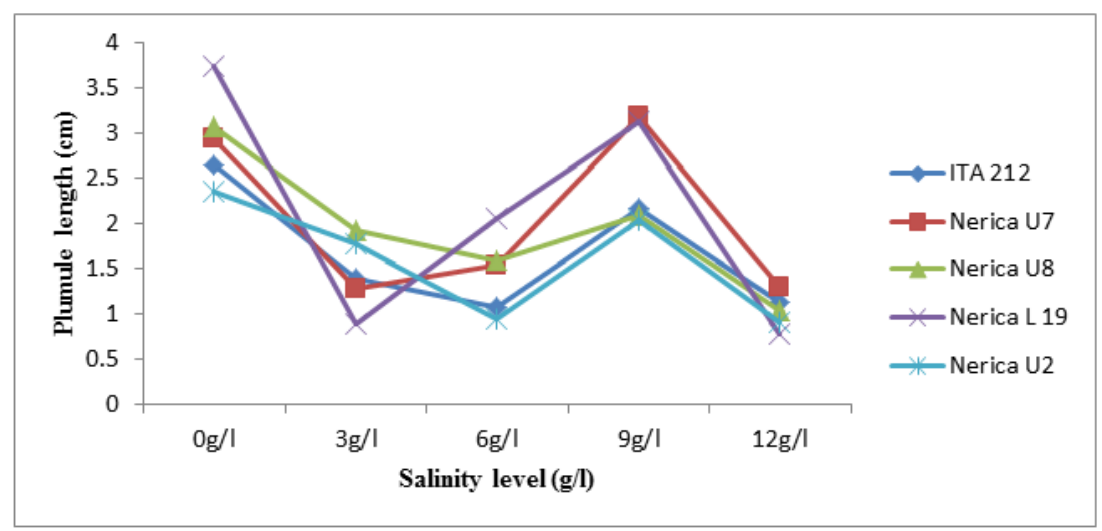

Fig-1: Showing the effect of salinity on plumule length $(\mathrm{cm})$ 


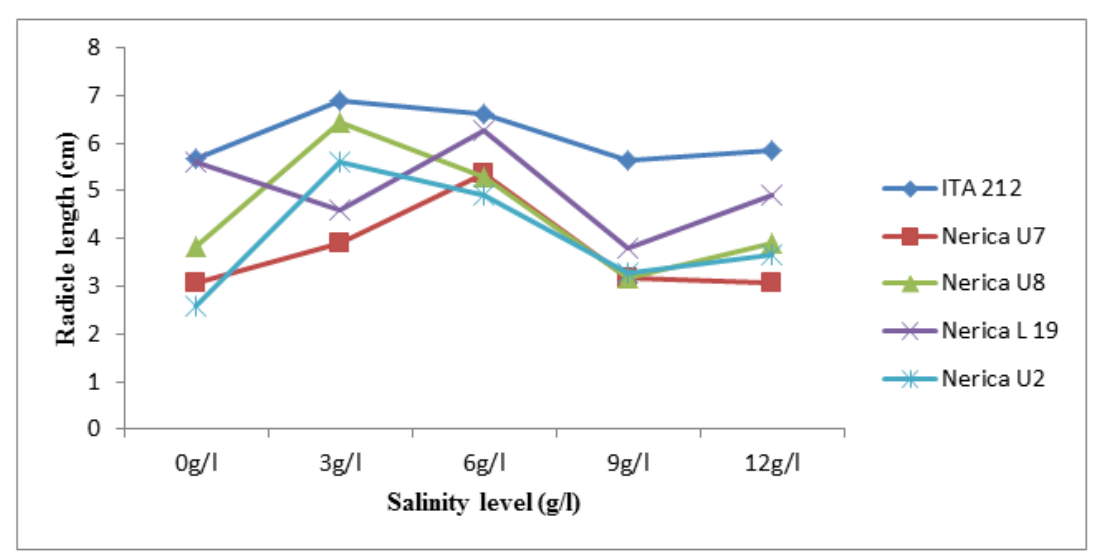

Fig-2: Showing the effect of salinity on radicle length $(\mathrm{cm})$

\section{Plumule and Radicle Dry Weight}

Effect of salinity treatments on plumule and radicle dry weights are presented in Tables 4 and 5 . Plumule and radicle dry weights showed progressive response to salt concentrations at $3 \mathrm{~g} / \mathrm{l}, 6 \mathrm{~g} / \mathrm{l}, 9 \mathrm{~g} / \mathrm{l}$ and $12 \mathrm{~g} / /$ respectively. At $3 \mathrm{~g} / \mathrm{l}$ Nerica U-2 had the lowest percentage dry weight $(19.35 \%)$ response to salt concentration while the highest $52.9 \%$ was found in Nerica U-8. Nerica U-2 maintained the same status with the lowest reaction to salt concentration $32.25 \%$ at $6 \mathrm{~g} / \mathrm{l}$ concentration and the highest $52.5 \%$ was observed in Nerica U-7. Nerica U-8 had the lowest (38.46\%) and highest $67.5 \%$ in Nerica U-7 at 9g/l salt concentration but it was obvious that plumule dry weight responded relatively very high to salt concentrations at $12 \mathrm{~g} / \mathrm{l}$ ranging from $64.51 \%-79.47 \%$ in Nerica $\mathrm{U}-2$ and Nerica $\mathrm{L} 19$ respectively. The response of radicle dry weight to varying salt concentrations is not different with $6.66 \%$ in Nerica L 19 which is lowest and $40.54 \%$ in Nerica U-8 as highest in $3 \mathrm{~g} / \mathrm{l}$ salt concentration. The variation observed in radicle dry weight at $6 \mathrm{~g} / \mathrm{l}$ showed that the effect was lowest in Nerica U-2 (28.57\%) and highest in Nerica U-8 (59.45\%). However, the reactions of the radicle dry weight to salt concentrations at $9 \mathrm{~g} / \mathrm{l}$ and $12 \mathrm{~g} / \mathrm{l}$ is more pronounced compared to lower concentrations of salinity treatment.

\section{Influence of salinity on total dry matter production}

The salinity score for tolerance and susceptibility of the five rice genotypes were presented in Table 6. At $3 \mathrm{~g} / \mathrm{l}$ all the rice genotypes were moderately tolerant (MT) except Nerica U-2 showed the highest degree of tolerance to salt concentration at that level. At $6 \mathrm{~g} / \mathrm{l}$ only Nerica U-2 was moderately tolerance while the remaining four genotypes show moderate susceptibility (MS) to the influence of salt. ITA 212 and Nerica U-7 were susceptible to salinity at 9g/l concentration while the remaining three; Nerica U-8, Nerica L 19 and Nerica U-2 were moderately susceptible. All the rice genotypes showed clear cut susceptibility to salt concentration at 12g/l. Similarly, it was reported by Jamil and Rha [14] that shoot length, root length and dry weight were decreased with increasing salt stress. This result was also confirmed by Fageria [9] who classified rice cultivar based on the dry matter of plant tops of the 8 cultivar out 54 and observed that the salinity level of $5 \mathrm{ds} / \mathrm{m}$, almost all the 8 cultivars were tolerance, while at $15 \mathrm{ds} / \mathrm{m}$ all the varieties were susceptible and at $10 \mathrm{ds} / \mathrm{m}$ the cultivar shows intermediate tolerances.

Table-4: Effect of salinity on plumule dry weight $(\mathrm{g} / \mathrm{l})$ of different rice genotypes

\begin{tabular}{|l|l|l|l|l|l|}
\hline Genotypes & $\mathbf{0} \mathbf{g} / \mathbf{l}$ & $\mathbf{3} \mathbf{g} / \mathbf{1}$ & $\mathbf{6} \mathbf{g} / \mathbf{l}$ & $\mathbf{9} \mathbf{~} / \mathbf{l}$ & $\mathbf{1 2} \mathbf{g} / \mathbf{l}$ \\
\hline ITA212 & 0.025 & $0.017(32.00)$ & $0.014(44.00)$ & $0.009(64.00)$ & $0.008(68.00)$ \\
\hline NERICA U-7 & 0.040 & $0.028(30.00)$ & $0.019(52.50)$ & $0.013(67.5)$ & $0.012(70.00)$ \\
\hline NERICA U-8 & 0.026 & $0.024(52.9)$ & $0.017(34.61)$ & $0.016(38.46)$ & $0.007(69.23)$ \\
\hline NERICA L-19 & 0.051 & $0.038(25.49)$ & $0.026(49.01)$ & $0.026(49.09)$ & $0.012(79.47)$ \\
\hline NERICA U-2 & 0.031 & $0.025(19.35)$ & $0.021(32.25)$ & $0.015(51.61)$ & $0.011(64.51)$ \\
\hline
\end{tabular}

Note: Percentage of dry weight in parenthesis

Table-5: Effect of salinity on radicle dry weight $(\mathrm{g} / \mathrm{l})$ of different rice genotypes

\begin{tabular}{|l|l|l|l|l|l|}
\hline GENOTYPES & $\mathbf{0 g} / \mathbf{l}$ & $\mathbf{3 g} / \mathbf{6}$ & $\mathbf{6 g} / \mathbf{9} / \mathbf{l}$ & $\mathbf{1 2 g} / \mathbf{l}$ \\
\hline ITA212 & 0.026 & $0.022(15.38)$ & $0.015(42.30)$ & $0.010(61.53)$ & $0.007(73.07)$ \\
\hline NERICA U-7 & 0.035 & $0.028(20.00)$ & $0.024(31.42)$ & $0.014(60.00)$ & $0.011(68.57)$ \\
\hline NERICA U-8 & 0.037 & $0.022(40.54)$ & $0.015(59.45)$ & $0.013(64.86)$ & $0.011(70.27)$ \\
\hline NERICA L-19 & 0.048 & $0.040(6.66)$ & $0.031(35.41)$ & $0.020(58.33$ & $0.013(72.91)$ \\
\hline NERICA U-2 & 0.035 & $0.031(11.42)$ & $0.025(28.57)$ & $0.018(48.57)$ & $0.010(71.42)$ \\
\hline
\end{tabular}

Note: Percentage of dry weight in parenthesis 
Table-6: Influence of salinity on total dry matter production $(\mathrm{g} / 10)$ of rice genotypes and their classification to salinity tolerance

\begin{tabular}{|l|l|l|l|l|l|}
\hline GENOTYPES & \multicolumn{3}{|l|}{ SALINITY } & \multicolumn{2}{l|}{ SCORE } \\
\hline & $0 \mathrm{~g} / \mathrm{l}$ & $3 \mathrm{~g} / \mathrm{l}$ & $6 \mathrm{~g} / \mathrm{l}$ & $9 \mathrm{~g} / \mathrm{l}$ & $12 \mathrm{~g} / \mathrm{l}$ \\
\hline ITA212 & 0.051 & $0.039 \mathrm{MT}$ & $0.029 \mathrm{MS}$ & $0.019 \mathrm{~S}$ & $0.015 \mathrm{~S}$ \\
\hline NERICAU-7 & 0.075 & $0.056 \mathrm{MT}$ & $0.043 \mathrm{MS}$ & $0.027 \mathrm{~S}$ & $0.023 \mathrm{~S}$ \\
\hline NERICAU-8 & 0.061 & $0.046 \mathrm{MT}$ & $0.032 \mathrm{MS}$ & $0.029 \mathrm{MS}$ & $0.019 \mathrm{~S}$ \\
\hline NERICA L-19 & 0.099 & $0.078 \mathrm{MT}$ & $0.057 \mathrm{MS}$ & $0.046 \mathrm{MS}$ & $0.025 \mathrm{~S}$ \\
\hline NERICA U-2 & 0.66 & $0.056 \mathrm{~T}$ & $0.046 \mathrm{MT}$ & $0.033 \mathrm{MS}$ & $0.021 \mathrm{~S}$ \\
\hline
\end{tabular}

Note: Tolerance (T), moderately tolerance (MT), Susceptible (S), Moderately Susceptible (MS)

\section{CONCLUSION}

From the experiment it was concluded that germination in early seedling growth up to vegetative and reproductive stages of the different five genotypes were inhibited by increase in salt concentrations, in respect of final germination percentages, speed of germination and germination energy. The genotypes with high GE\% at specific salinity level obviously would be of higher competitive advantages than genotypes with lower GE\% for capturing environmental and adaptive resources. Therefore, Nerica U-2 was moderately tolerance to salinity at $6 \mathrm{~g} / \mathrm{l}$ salt concentration and is hereby recommended for saline soils.

\section{REFERENCES}

1. Food and Agricultural Organization. (1996). International Rice Commision Newsletter. 1996; 48 - FAO www.fao.org/docrep/003/X2243T/x2243t05.htm

2. Houshmand, S., Arzani, A., Maibody, S. A. M., \& Feizi, M. (2005). Evaluation of salt-tolerant genotypes of durum wheat derived from in vitro and field experiments. Field Crops Research, 91(2-3), 345-354.

3. Hosseini, S. J., Tahmasebi, S. Z., \& Pirdashti, H. (2012). Screening of rice (Oryza sativa L.) genotypes for NaCl tolerance at early seedling stage. International Journal of Agronomy and Plant Production, 3(8), 274-283.

4. Yeo, A. R., \& Flowers, T. J. (1983). Varietal differences in toxicity of sodium ions within the shoot of rice varieties differing in salinity resistance. Physiol. Plant, 56, 343-348.

5. Yeo, A. R., Yeo, M. E., Flowers, S. A., \& Flowers, T. J. (1990). Screening of rice (Oryza sativa L.) genotypes for physiological characters contributing to salinity resistance, and their relationship to overall performance. Theoretical and Applied Genetics, 79(3), 377-384.

6. Pitman, M. G., \& Läuchli, A. (2002). Global impact of salinity and agricultural ecosystems. In Salinity: environment-plantsmolecules. Springer, Dordrecht. 3-20.

7. Gu, X. Y., Yan, X. L., Zheng, S. L., \& Lu, Y. G. (1999). Influence of salinity on genetic variation of agronomic traits in rice. Sci Agric Sin, 32(1), 1-7.

8. Ellis, R. A., Robert. (1981). The qualification of aging and survival in orthodox seeds. Seed Sci. Technol, 9 373-409.

9. Fageria N. K. (1985). Salt tolerance of rice cultivars. Plant Soil. 88:237-243.

10. Akbar, M., Yabuno, T., \& Nakao, S. (1972). Breeding for Saline-resistant Varieties of Rice: I. Variability for Salt Tolerance among Some Rice Varietles. Japanese Journal of Breeding, 22(5), 277-284.

11. Khatun, S., Rizzo, C. A., \& Flowers, T. J. (1995). Genotypic variation in the effect of salinity on fertility in rice. Plant and soil, 173(2), 239-250.

12. Akbar, M., G. S. khush and D. Hilerislambers. (1986). Genetics of salt tolerance in rice. In Manila, Philippines (Ed.).IRRI. Rice Genetics. The International Rice Research Institute, 399-409.

13. Rahman, M. S., Miyake, H., \& Taheoka, Y. (2001). Effect of sodium chloride salinity on seed germination and early seedling growth of rice (Oryza sativa L.). Pak. J. Biol. Sci, 4(3), 351-355.

14. Jamil, M., \& Rha, E. S. (2007). Response of transgenic rice at germination and early seedling growth under salt stress. Pakistan journal of biological sciences: PJBS, 10(23), 4303-4306. 